\title{
INFLUENCE OF MYCORRHIZAE AND INORGANIC FERTILIZ- ER ON PLANT GROWTH AND YIELD COMPONENTS OF TWO SRI LANKAN TRADITIONAL RICE ACCESSIONS (Oryza sativa L)
}

\author{
Dahanayake Nilanthi* and CJ Alawathugoda
}

Department of Agricultural Biology, Faculty of Agriculture, University of Ruhuna, Mapalana, Kamburupitiya, Sri Lanka

\begin{abstract}
A greenhouse experiment was conducted to determine the influence of mycorrhizae as a substitute for inorganic fertilizer on growth and yield of two traditional rice (Oryza sativa L.) varieties namely, "Bathkiriel" and "Sinnanayam", and on soil microbial activity. The experiment was conducted in pots $(30 \mathrm{~cm} \times 30 \mathrm{~cm} x 45 \mathrm{~cm})$ filled with paddy soil treated separatelywith four doses of inorganic fertilizers, i.e. the recommended dose of basal fertilizer UREA:TSP:MOPat 50:62.5:50kg/ha and top dressing Ureaat87.5kg/ha, $1 / 2$ and $1 / 4$ of the recommend doses of inorganic fertilizers, and no inorganic fertilizer. In addition commercially available mycorrhizae (diluted at2g of mycorrhizae mixture $/ 5 \mathrm{~L}$ water) was added to all pots except those received the total dose of inorganic fertilizers. The above four treatments were replicated four times in a Completely Randomized Design (CRD) with four replicates. The experiment revealed that there was no significant difference in all growth parameters in plants treated with recommended dose and those treated with $1 / 2$ of recommended dose of inorganic fertilizer with standard dose of mycorrhizae. The highest soil microbial activity was recorded in soil treated with standard dose of mycorrhizae without inorganic fertilizer $\left(5,660 \mathrm{CO}_{2} \mathrm{mgkg}^{-1}\right.$ of soil)as compared to those treated only with inorganic fertilizer (4,662 $\mathrm{CO}_{2} \mathrm{mgkg}^{-1}$ of soil). Mycorrhizaefound to increase soil microbial activity significantly and complementary to inorganic fertilizer.Itwas concluded that $1 / 2$ of the recommended dose of inorganic fertilizer with standard dose of mycorrhizae was the best fertilizer mixture out of the tested mixtures for traditional rice varieties "Bathkiriel" and "Sinnanayam".
\end{abstract}

Key words: Mycorrhizae, Inorganic fertilizer, Rice variety Bathkiriel and Sinnanayam

\section{INTRODUCTION}

Rice (Oryza sativa: Poaceae) is a cereal crop and it is with tremendous economic importance. It is a staple food for a large human population in the world. It is feared that world population would be around 10 billion by 2050. Thus more food will be required to feed the human population. This will be in the backdrop of diminishing cultivated land. Studies are underway to increase yield as well as quality of rice. Sri Lanka is considered as a valuable repository of crop germplasm and agrobiodiversity. It has a rich treasure of rice genes and over 2,800 varieties have been recorded in

*Corresponding author: nilanthi@agbio.ruh.ac.lk the country (https://www.beyondescapes.lk/ agro-tourism-in-sri-lanka/). These varieties show great adaptability to a wide range of climatic and soil conditions as well as pest and disease problems. They also exhibit variation in grain size and quality, some with medicinal properties and fragrance and others that are used for cultural and ritual reasons also show differences in maturity period. (http:// goviya.com/agro-biodiversity2.htm). In spite of all these benefits, traditional rice are still not favored for commercial scale cultivation due to their low yield potential, which cannot satisfy the current market demand. Therefore new avenues must be developed for improving agronomic characters of traditional rice 
varieties, which would give a higher yield. One of such approaches would be, enhancement of the nutritional status of the plant using effective approaches.

Inorganic fertilizer application enhances plant growth and yield because it absorbs quickly from soil to plants. Therefore, farmers apply recommended amount of inorganic fertilizer to their crops to achieve a higher yield. As a result of the excessive applications of inorganic fertilizer leaches to the ground causes water pollution. Mycorhizae can be used as biofertilizer as it helps to improve the quality of soil as well as the yield of the plants. To minimize this situation, a combination of inorganic fertilizer with biological ingredients is better to use in crop cultivation (Urban Creeks Council, 2012). Mycorrhiza (family Endogone) is a type of organic fertilizer/bio fertilizer creates mutualistic symbiosis between mycorrhizal fungi and higher plants. Mycorrhizae improve crop yield and increase the use of inorganic fertilizer by forming a bridge between the roots and the soil (University of Washington, 2006). It indirectly enhances the structure of the soil and improves air and water infiltration.

Present study was conducted to find the growth and yield responses of traditional rice (variety "Bathkiriel" and variety "Sinnanayam") with mycorrhizae as a substitute for inorganic fertilizer. The main objective of this study was to develop a better fertilizer combination (Inorganic fertilizer with Mycorrizae) for the optimum growth and yield of traditional rice varieties Bathkiriel and Sinnanayamas well as compare the soil microbial activity of treated and untreated soils from paddy field.

\section{MATERIALS AND METHODS}

This study was conducted at the Faculty of Agriculture, University of Ruhuna, Mapalana, Kamburupitiya (AMSL 100m; annual rainfall > $1,900 \mathrm{~mm}$; mean monthly temperature $27^{\circ} \mathrm{C}$ and relative humidity $72 \%$ ). Seeds of randomly selected rice varieties, "Bathkiriel" and
"Sinnanayam", were obtained from the Plant Genetic Resource Centre, Ganoruwa, Peradeniya. Seed nurseries were established on plastic trays filled with soil collected form the rice fields. After twenty one days of nursery period healthy same size $(15 \mathrm{~cm})$ seedlings were transplanted in plastic-pots $(30 \mathrm{~cm} \times 30 \mathrm{~cm} \times 45 \mathrm{~cm})$ filled with soil treated by Thiaophanate methyl $70 \mathrm{WP}(0.6 \mathrm{gL}-1$ water $)$ and maintained three plants per pot. Weaker plants were thinned out after 10-12 days leaving two; plants per pot. The plants were watered regularly to maintain soil moisture. The pots were treated with four doses of inorganic fertilizer - T1: applied dose of basal fertilizer UREA:TSP:MOP at 50:62.5:50kgha-1 and Top dressing Urea at 87.5kgha-1, (T2: 1/2 applied dose of inorganic fertilizer, T3: $1 / 4$ of the applied dose of inorganic fertilizer and T4: no inorganic fertilizer. In addition, mycorrhizae ( $0.5 \mathrm{gL}-1$ water) were added to all pots except those received total inorganic fertilizer dose. All management practices were conducted according to recommendations of the Department of Agriculture from seed germination to harvesting. Shoot length $(\mathrm{cm})$, root length $(\mathrm{cm})$, plant dry weight $(\mathrm{g})$, No. of panicles per plant, panicle dry weight (g), No. of grains per panicle, 100 seed weight (g) and microbial activity (procedure given below) were measured. The experiment was carried out according to Completely Randomized Design (CRBD) with four replicates and 8 plants per replicate. Data were analyzed using SAS program (9.1.3).

\section{Determination of soil microbial activity}

Soil microbial activity was measured according to the $\mathrm{CO}_{2}$ evolution method. Soil sample (10 g) from the paddy cultivated pots from the different treatments were taken into a jam bottle before harvesting and mixed with $3.5 \mathrm{ml}$ distilled water. The controller set was filled with $3.5 \mathrm{ml}$ of distilled water. Ignition tube was filled with $3 \mathrm{ml}$ of $2 \mathrm{~N}-\mathrm{NaOH}$ and then placed on the glass bottle so that the emitted $\mathrm{CO}_{2}$ from the soil will be absorbed in to the $\mathrm{NaOH}$ solution. Soil samples were kept in dark room for 
one week. Then contents in ignition tubes were washed in to $250 \mathrm{ml}$ conical flasks separately and mixed with $7.5 \mathrm{ml}$ of $2 \mathrm{~N} \mathrm{BaCl}_{2}$. Few drops of phenolphthalein were added and mixtures were titrated by $0.5 \mathrm{~N}-\mathrm{HCl}$. Burette reading was taken at the point of solution color changes from pink to colorless.

\section{RESULTS AND DISCUSSION}

According to the results, there was no significant difference between the treatments of the $1 / 4$ of the recommended dose of inorganic fertilizer+ micorrhizae and the sole micorrhizae treatment with respect to all the parameters tested in both rice varieties. Comparatively, only organic fertilizer and $1 / 2$ recommended dose of inorganic fertilizer+ micorrhizae treatments displayed significantly higher values of the same parameters in both the tested rice varieties. In case of both rice varieties, the root length was significantly higher when treated with $1 / 2 \mathrm{IF}+$ micorrhizae than IF alone (Tables 1a and $\mathrm{Ib}$ ). This observation indicate that micorrhizaehas a positive influence in root growth. Similarly Seranet al, (2010) have indicated that mycorrhizae helped to increase

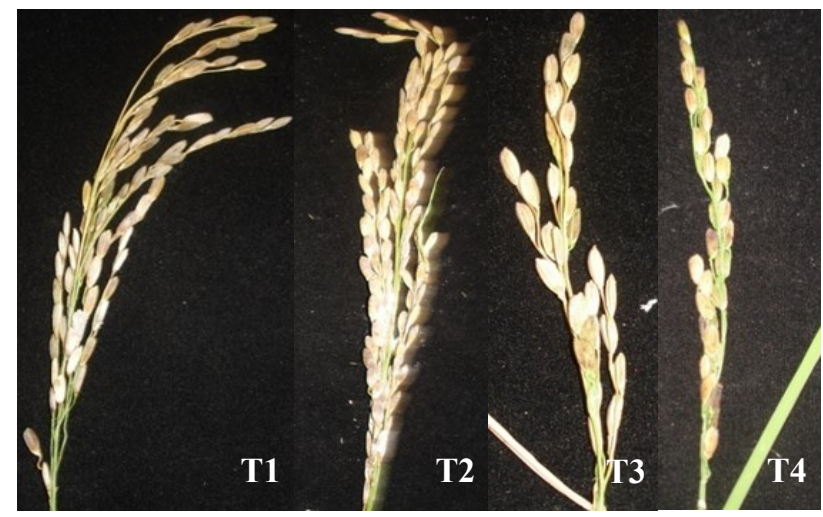

Fig. 1.Panicles of rice from different treatment. [recommended dose (T1), 1/2 recommended dose (T2) and 1/4 recommended dose (T3) and 0 recommended dose (T4)]

Table 1a. Growth parameters of rice variety Bathkiriel treated with different combinations of inorganic fertilizer (IF) and mycorrhizae (M)

\begin{tabular}{clllllll}
\hline Treatments & $\begin{array}{l}\text { Shoot } \\
\text { Length } \\
\text { (cm) }\end{array}$ & $\begin{array}{l}\text { Root } \\
\text { Length } \\
\text { (cm) }\end{array}$ & $\begin{array}{l}\text { Plant dry } \\
\text { weight }(\mathbf{g})\end{array}$ & $\begin{array}{l}\text { No. of } \\
\text { Panicles } \\
\text { per plant }\end{array}$ & $\begin{array}{l}\text { Panicle } \\
\text { dry } \\
\text { weight }(g)\end{array}$ & $\begin{array}{l}\text { No. of } \\
\text { grains per } \\
\text { panicle }\end{array}$ & $\begin{array}{l}\text { 100 seed } \\
\text { weight } \\
\text { (g) }\end{array}$ \\
\hline Only IF & $91.22 \mathrm{a}$ & $4.50 \mathrm{~b}$ & $34.90 \mathrm{a}$ & $2.31 \mathrm{a}$ & $5.74 \mathrm{a}$ & $70.70 \mathrm{a}$ & $3.20 \mathrm{a}$ \\
$1 / 2 \mathrm{IF}+\mathrm{M}$ & $92.81 \mathrm{a}$ & $7.52 \mathrm{a}$ & $33.33 \mathrm{a}$ & $2.24 \mathrm{a}$ & $5.20 \mathrm{a}$ & $69.02 \mathrm{a}$ & $3.10 \mathrm{a}$ \\
$1 / 4 \mathrm{IF}+\mathrm{M}$ & $75.34 \mathrm{~b}$ & $8.72 \mathrm{a}$ & $13.12 \mathrm{~b}$ & $1.50 \mathrm{~b}$ & $3.00 \mathrm{~b}$ & $45.22 \mathrm{~b}$ & $2.22 \mathrm{~b}$ \\
Only M & $69.60 \mathrm{~b}$ & $9.80 \mathrm{a}$ & $11.22 \mathrm{~b}$ & $1.30 \mathrm{~b}$ & $2.52 \mathrm{~b}$ & $40.40 \mathrm{~b}$ & $2.01 \mathrm{~b}$ \\
\hline
\end{tabular}

Table 1b. Growth parameters of Rice variety Sinnanayam treated with different combinations of inorganic fertilizer (IF) and mycorrhizae (M)

\begin{tabular}{ccccllll}
\hline Treatments & $\begin{array}{l}\text { Shoot } \\
\text { Length } \\
\text { (cm) }\end{array}$ & $\begin{array}{l}\text { Root } \\
\text { Length } \\
(\mathbf{c m})\end{array}$ & $\begin{array}{l}\text { Plant dry } \\
\text { weight }(\mathbf{g})\end{array}$ & $\begin{array}{l}\text { No. of } \\
\text { Panicles } \\
\text { per plant }\end{array}$ & $\begin{array}{l}\text { Panicle } \\
\text { dry } \\
\text { weight }(\mathbf{g})\end{array}$ & $\begin{array}{l}\text { No. of } \\
\text { grains per } \\
\text { panicle }\end{array}$ & $\begin{array}{l}\mathbf{1 0 0} \\
\text { seed } \\
\text { weight } \\
\text { (g) }\end{array}$ \\
\hline Only IF & $97.64 \mathrm{a}$ & $9.20 \mathrm{~b}$ & $13.92 \mathrm{a}$ & $3.50 \mathrm{a}$ & $5.34 \mathrm{a}$ & $92.71 \mathrm{a}$ & $3.90 \mathrm{a}$ \\
$1 / 2 \mathrm{IF}+\mathrm{M}$ & $95.83 \mathrm{a}$ & $11.81 \mathrm{a}$ & $14.10 \mathrm{a}$ & $3.31 \mathrm{a}$ & $5.70 \mathrm{a}$ & $91.32 \mathrm{a}$ & $3.80 \mathrm{a}$ \\
$1 / 4 \mathrm{IF}+\mathrm{M}$ & $79.83 \mathrm{~b}$ & $11.71 \mathrm{a}$ & $9.90 \mathrm{~b}$ & $1.51 \mathrm{~b}$ & $3.21 \mathrm{~b}$ & $63.81 \mathrm{~b}$ & $2.61 \mathrm{~b}$ \\
Only M & $75.00 \mathrm{~b}$ & $13.31 \mathrm{a}$ & $6.60 \mathrm{~b}$ & $1.30 \mathrm{~b}$ & $2.61 \mathrm{~b}$ & $61.11 \mathrm{~b}$ & $2.51 \mathrm{~b}$ \\
\hline
\end{tabular}

Column values followed by the same letter are not significantly different as determined by Duncan's multiple range test $(\mathrm{P}=0.05)$. 
root surface area under adverse soil conditions.In this experiment,the highest soil microbial activity was recorded in soil treated with standard dose of mycorrhizae without inorganic fertilizer $\left(5,660 \mathrm{CO}_{2} \mathrm{mgkg}^{-1}\right.$ of soil). It was significantly different from the values in all the other inorganic fertilizer treated samples.Similar results were observed by Seranet al(2010)who observed that soil micro and macro organisms were reduced in the presence of inorganic fertilizers as compared to organic fertilizers. It is concluded that $1 / 2$ of the recommended dose of inorganic fertilizer with standard dose of mycorrhizae is the best fertilizer mixture for rice varieties Bathkiriel and Sinnanayam (Fig. 3). The reasons underline the above observations may be the low nutrient content intake through mycorrhizae does not satisfy the nutrient demand of the growing rice as compared to the nutrients in inorganic fertilizer which is readily available for plant uptakes (Ramanie et al, 2008).

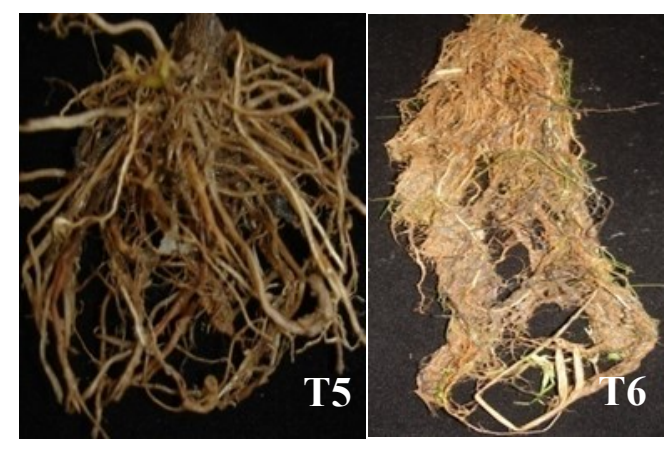

Fig. 2. Roots of rice plant from recommended dose of inorganic fertilizer without mycorrhizae (T1), and Standard dose of mycorrhizae without Inorganic fertilizer (T4).

\section{CONCLUSION}

Half of the recommended dose of inorganic fertilizer and standard dose of mycorrhizae $\left(2 \mathrm{~g} \mathrm{~L}^{-1}\right)$ found to be the best fertilizer mixture for higher productivity of both tested traditional rice varieties, "Bathkiriel" and "Sinnanayam". Mycorrhizae found to compliment $1 / 2$ dose of inorganic fertilizer and increased soil microbial activity significantly.

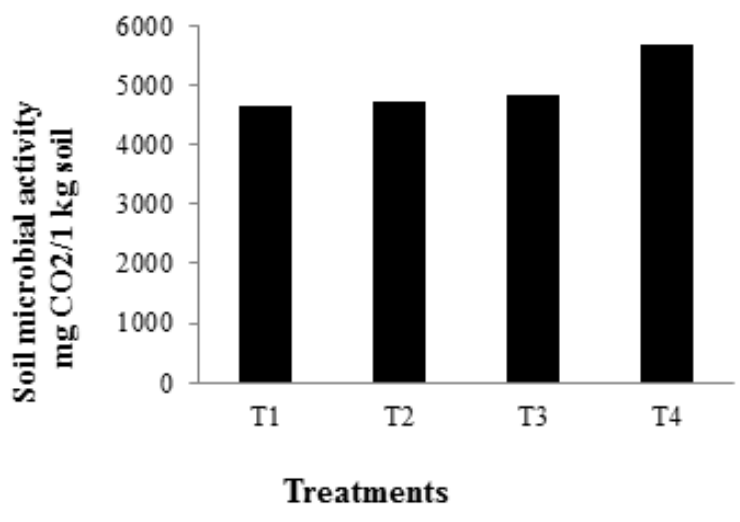

Figure 3. Soil microbial activity of treated soil medium with inorganic fertilizer and mycorrhizae.

* Means followed by the same lower case letters in each column are not significantly different at 5\% probability level in Duncan's Multiple Range Test.

\section{REFERENCE}

Ramanie KH, Baker JH and Baker AV 2008 Benefits of mycorrhizae to soybeans grown on various regimes of nitrogen nutrition, Journal of Plant Nutrition, Retrieved September 3, 2012, From www.tandfonline.com

Seran, TH, Srikrishnah, S, Ahamed, MMZ 2010 Effect of different levels of inorganic fertilizers and compost as basal application on the growth and yield of onion (Allium cepa L.), The Journal of Agricultural Sciences, vol. 5, no 2.

University of Washington 2006 Retrieved August 07, 2012, from http://green-diamond -biological.com/wp-content/ uploads/2012/03/Mycorrhiza-article.pdf5

Urban Creeks Council n.d., Bio fertilizers and Mycorrhizae, Retrieved August 24, 2012, from http://www.urbancreeks.org/ Biofertilizers.pdf 